\title{
Jméno: jeho změna, ztráta a navrácení v rozhovorech s židovskými přžživšími holocaustu*
}

\author{
KAROLÍNA BUKOVSKÁ** - JAKUB MLYNÁŘ***
}

Name: its Change, Loss and Return in Holocaust Survivors' Testimonies

\begin{abstract}
This article aims to explore the personal name as an aspect of human identity, based on our analysis of several tens of oral-history autobiographical interviews from the USC Shoah Foundation's Visual History Archive (http://vhaonline.usc.edu). The text reflects on the transformations and meanings of name in the war and post-war period, focusing on the compulsory and voluntary name change, but also its loss and supplementation by the (tattooed) number in the concentration camps. In this context we also pay attention to the tattoo as a component of social identity of the Holocaust survivor and different attitudes. In the concluding parts of the text, we also investigate the post-war commemoration of the Holocaust as a process, which aims to return the lost names to the victims of the Nazi genocide of people labelled as "Jews". Our research points to the tendency to understand name and identity as an indivisible duality, which is mutually influenced. At the same time, it suggests that the loss of name or its compulsory change is not reflected by the survivors as an especially traumatic experience, in the context of following events. A particular symbolic value of personal name can be seen in the cases of the people murdered during the Holocaust, and in the context of current commemorative activities the naming of Shoah victims is of central importance.
\end{abstract}

Keywords: name; identity; Holocaust; Shoah; oral history; tattoo; commemoration

DOI: $10.14712 / 23363525.2019 .20$

\section{Úvod}

Po osmdesáti letech od vypuknutí druhé světové války se nevyhnutelně dostáváme do situace, kdy se s přeživšími holocaustu a jejich životními osudy můžeme nadále setkávat pouze prostřednictvím orálněhistorických rozhovorů, které s nimi byly v minulosti natočeny. Nutno podotknout, že takových rozhovorů rozhodně není málo. Díky rozmachu orální historie [srov. Mücke - Vaněk 2012] máme dnes k dispozici desítky tisíc rozhovorů s lidmi, kteří byli pronásledováni nacistickým režimem a přežili internaci v koncentračních táborech. Paradoxně se tak i v době „post-pamětnické“ můžeme (alespoň virtuálně) seznámit s daleko větším počtem životních příběhů, než se minulým generacím podařilo při osobních setkáních s přeživšími.

\footnotetext{
* Vznik studie byl financován grantem Grantové agentury České republiky (GAČR) Začlenění židovského obyvatelstva do poválečného Československa a Polska č. 16-01775Y, který byl v letech 2016-2018 řešen na Ústavu pro soudobé dějiny Akademie věd České republiky. Rádi bychom poděkovali dvěma anonymním recenzentům za podnětné komentáře a náměty k první verzi textu.

** Bc. Karolína Bukovská, Fachbereich Geschichts- und Kulturwissenschaften, Friedrich-Meinecke-Institut, Freie Universität Berlin, Koserstraße 20, 14195 Berlin. E-mail: karolina.bukovska@fu-berlin.de

*** Mgr. Jakub Mlynáŕ, Ph.D., Katedra sociologie Filozofické fakulty Univerzity Karlovy, Náměstí Jana Palacha 2, 11638 Praha 1.E-mail: jakub.mlynar@ff.cuni.cz
} 
Vzhledem k nepřebernému množství rozhovorů však vyvstává otázka, jak s těmito svědectvími smysluplně naložit. Jednou $\mathrm{z}$ možností je přistupovat $\mathrm{k}$ interview nejen $\mathrm{z}$ pozice historického výzkumu, ale také perspektivou jiných disciplín. Pohnuté osudy přeživších holocaustu sice v prvé řadě představují cenný zdroj informací o dané době, jejich vyprávění o vlastních životních zkušenostech nám však mohou zároveň leccos prozradit např́klad o identitě narátorek a narátorů. Právě jednomu z aspektů lidské identity se věnuje tento článek.

Kromě stručného teoretického uvedení je tento text založen na empirickém zkoumání, a to prostřednictvím kvalitativní sekundární analýzy vzorku orálně-historických rozhovorů shromážděných v Archivu vizuální historie USC Shoah Foundation (dále VHA; viz http://vhaonline.usc.edu), který je v ČR k dispozici i na Univerzitě Karlově [viz Mlynár 2013, 2015, 2016, či webové stránky http://ufal.mff.cuni.cz/malach]. Základem této on-line databáze je na 54500 audiovizuálních nahrávek interview s lidmi, kteří přežili holocaust. Rozhovory s nimi byly vedeny ponejvíce v 90 . letech 20 . století, v mnoha evropských i mimoevropských státech a v téměř 40 různých jazycích (v původním znění bez titulků). Jedná se o celoživotní vyprávění daného pamětníka či pamětnice (s více či méně závažnými vstupy tazatelek a tazatelů), které je chronologicky strukturováno a v průměru trvá dvě a čtvrt hodiny. Vzhledem k rozsahu archivu je nezbytné, aby badatelé a další uživatelé mohli v databázi efektivně a rychle vyhledávat. Proto je v uživatelském rozhraní k dispozici např. rozsáhlý rejstř́́k klíčových slov (přes 65000 položek) a databáze více než jednoho milionu osobních jmen [podrobněji viz Mlynár - Kocian - Bukovská - Chudomelová 2017].

Cílem našeho textu je na základě vybraných videonahrávek interview z VHA ${ }^{1}$ sledovat proměny a významy jednoho $z$ atributů identity - jména [Bourdieu 1998: 59]. To se totiž především u židovských přeživších šoa ukazuje jako velmi proměnlivý identifikační prvek. ${ }^{2}$ Středem zájmu tohoto článku proto budou životní zkušenosti židovských přeživších holocaustu související právě se změnou či ztrátou jména. ${ }^{3}$ Za jakých okolností u narátorek a narátorů docházelo ke změně jejich jména a jaký postoj ke změně zaujali? Jak vnímali ztrátu svého jména, především v souvislosti s internací v koncentračním táboře, kde byla jejich jména nahrazena vězeňskými čísly? Co pro přeživší šoa znamenají vězeňská čísla vytetovaná na jejich předloktí? V neposlední řadě bude v tomto textu věnována

1 Výběr proběhl na základě vyhledávání kombinací klíčových slov „name changes“, „compulsory name changes“, „prisoner identification number“, „prisoner tattoo removal“ a dalších. Rozhovory analyzované v tomto článku byly převážně v anglickém jazyce, s výjimkou interview č. 34 (němčina) a 40 (čeština). Při výběru jsme nijak nezohledňovali národnost či zemi původu jednotlivých narátorek a narátorů.

2 Užívání slova holocaust narůstá od 60. let 20. století jako označení genocidy zejména „židovského“ obyvatelstva (v některých definicích rozšířeno i na další skupiny obětí perzekuce - Romy a jiná etnika, homosexuály, politické vězně) během druhé světové války ze strany nacistů a jejich přisluhovačů. Termínu holocaust se v této souvislosti zpravidla užívá v dvojím významu: ve svém širším vymezení je užíván pro označení nacistické genocidy „nežádoucích“ skupin obyvatelstva v letech 1933-1945. V užším významu bývá tento termín užíván pro perzekuci lidí označených na základě tzv. norimberských zákonů za osoby židovského původu a následnou genocidu takto označených osob. Termín šoa (hebrejsky „katastrofa“) je dnes ve vztahu ke genocidě Židů a osob označených za Židy používán častěji než termín holocaust a sémanticky se překrývá s právě zmíněným užším vymezením holocaustu: slovem šoa je tedy míněna nacistická perzekuce a vyvražd’ování osob označených za Židy mezi lety 1933-1945.

3 Pro účely tohoto textu slouží pojem „jméno“ jako souhrnné označení pro rodné (křestní) jméno (např. Jan) a př́imení (např. Novák) zároveň. „Změnou jména“ se v tomto kontextu rozumí změna bud’ rodného jména, či př́ijmení, či obou jmen současně. 
pozornost i otázce, jakou roli hraje jméno při uctívání obětí holocaustu během komemorativních aktivit.

\section{Jméno jakožto identita člověka}

\section{"Ditě se učí, že je tím, jak mu říkají.“ [Berger - Luckmann 1999: 131]}

Jméno, na něž má dle Úmluvy o právech dítěte OSN každý narozený jedinec právo [Úmluva o právech dítěte 2015], představuje jeden ze základních prostředkủ, jimiž je v rámci lidské společnosti vyjadřována jedinečnost konkrétní osoby [Knappová 1989: 13]. Jak uvádí na př́kladu svého vlastního jména britská socioložka Janet Finch: „Mé jméno má dvě dimenze. Označuje mě jako jedinečného jedince a zároveň poskytuje určité indikace o mém zařazení do různých sociálních světů, které obývám - obsahuje moji právní osobnost jako britské občanky, odhaluje můj gender a pravděpodobně i etnicitu, zachycuje něco $\mathrm{z}$ mých rodinných vazeb, a v mém př́padě, přidám-li svůj titul ,profesor, také vyjadřuje mé zaměstnání [Finch 2008: 709]. ${ }^{4}$ Jméno, jež se v momentě narození stává naším základním identifikačním prvkem užívaným v soukromém i veřejném životě, je tedy zároveň jedním z prvních aspektů identity, jenž je člověku objektivně přidělen [Berger - Luckmann 1999: 131] společností (zprvu většinou rodiči). Pojmenování je proto nutné chápat jako sociolingvistický akt, jenž je daným společenským prostředím determinován [Knappová 1989: 8]. Tento akt probíhá vždy v určitém sociokulturním a situačním rámci a je vždy založen na aspektech kategorizace a identifikace [srov. Eglin - Hester 2003; Fitzgerald - Housley 2015]. Identita konkrétních jedinců a společenství může v tomto společenském prostředí nabývat různých podob a forem [srov. Mlynář 2014]. Sociologicky lze uvažovat o třech základních dimenzích identity, a to osobní, sociální a kolektivní identitě:

Osobní identita je soubor významů či určitý obraz konkrétní lidské bytosti založený na jedinečných charakteristikách, které ji významně odlišují od ostatních lidských bytostí. Sociální identita je soubor významů či určitý obraz konkrétní lidské bytosti založený na sociálních rolích a pozicích v sociální struktuře. Kolektivní identita je soubor významů či určitý obraz konkrétní lidské bytosti založený na její (přii)náležitosti $\mathrm{k}$ dalším lidem, tedy členství ve skupině, společenství, organizaci či (pomyslné) komunitě. [Mlynář 2017: 64]

Pojmenováním jedince danou společností je tedy kromě osobní identity založena i jeho sociální a kolektivní identita [Bourdieu 1998: 59]. S tou v okamžiku přijetí jména za své („Já jsem John Smith.") [Berger - Luckmann 1999: 131] jedinec zároveň vstupuje jako aktér do nové sociální existence [Bourdieu 1998: 61] a tím i do společenství, které jej pojmenovalo a které jeho individuální existenci jako Johna Smithe prostřednictvím jména uznalo [Knappová 1989: 6]. Identita může být zároveň vlastní a nevlastní: „Vlastní identita je reflexivní a ,subjektivní sebe-pojetí či mínění o sobě samém (ve vztahu k jedinci či společenství). Nevlastní identita je připsána ,zvenčí určitému jednotlivci nebo společenství na základě atributů, rysů a vlastností chápaných jako objektivní a směrodatné" [Mlynář 2017: 63].

4 Janet Finch ve svém článku konstatuje, že sociologický výzkum o osobních jménech je překvapivě málo rozpracován, sama se zde nicméně zaměřuje pouze na význam jmen v kontextu rodiny [Finch 2008: 710]. 
Vlastní a nevlastní identita mohou být v rozporu, vzájemně se ovlivňovat, ale i - jak ještě uvidíme dále - převracet jedna v druhou. Stejně jako identitu obecně, i jméno jakožto identitu sociální tedy charakterizuje dialektický vztah mezi jedincem a společností založený na uznání a zneuznání [Berger - Luckmann 1999: 171]. Jméno - na první pohled banální a samozřejmá záležitost - tak při hlubším zamyšlení bezesporu „představuje mimořádně komplikovaný útvar a pojmenování má povahu dynamické, živé a tvořivé a vlastně nekončící činnosti“ [Mokrejš 2013: 144].

V důsledku úzké svázanosti společnosti s aktem pojmenování [srov. Stivers - Enfield Levinson 2007: 2-7] jsou udělovaná jména jen zřídka bezpříznaková a často vypovídají o etnickém, sociálním, politickém či kulturním zázemí, ze kterého jeho nositel pochází [Knappová 1989: 78]. Tyto př́znaky, které s sebou jméno nese, se dostávají na povrch především při vstupu do cizí, respektive nové sociální skupiny. V takové chvíli může vzniknout tlak na asimilaci „cizorodého“ jména: „Při každém vstupu do nové sociální, popřípadě politicko-ideologické situace a společenské skupiny může jedinec dostat (popř́padě si zvolit) nové jméno, motivované podmínkami jeho sociální role a pozice“ [Knappová 1989: 80]. Právě v nových sociálních, a často politicko-ideologických situacích se nacházeli přeživší holocaustu, když u nich docházelo ke změně či ztrátě jména. Jak dále poznamenává Erving Goffman, „k některým změnám jména, jako v případě branců odpírajících nástup vojenské služby či motelových hostů, dochází s ohledem na právní aspekty osobní identifikace, zatímco k jiným, využívaným například příslušníky etnických menšin, dochází v souvislosti s otázkou sociální identity“ [Goffman 2003: 72-73].

\section{Jméno v rozhovorech s židovskými přeživšími holocaustu}

Skutečnost, že daná narátorka či narátor byli v průběhu svého života nositelem více jmen, vychází v rámci orálněhistorických rozhovorů mnohdy najevo již při první otázce tazatele či tazatelky. Na počátku rozhovoru totiž bývá pamětník či pamětnice zpravidla vyzván/a, aby se představil [např. interview č. 14, segment \#1]. V některých případech pak následuje doplňující dotaz tazatele či tazatelky, zda se narátor/ka takto jmenoval/a odjakživa, či zda za svého života užíval/a i jiných jmen [např. interview č. 37, segment \#1]. V tomto momentu, na samém začátku celého interview, se tak může začít odvíjet jedna $z$ epizod ze života pamětníka nebo pamětnice. Jméno, jímž se představí, může zároveň poodhalit, $\mathrm{z}$ jaké pozice narátor/ka v rozhovoru vystupuje.

Zkoumat okolnosti proměny osobního jména je hodné pozornosti především u židovských přeživších holocaustu. Jakožto náboženská skupina žijící po staletí na územích různých státních celků čelili židé zásahům do svých původních hebrejských jmen často nejen v dávné minulosti, ale především pak v 30. a 40. letech 20. století, a to nejen v kontextu nacistického režimu (například rodné hebrejské jméno Charlese D. ${ }^{5}$, „Chaim-Yehuda“, bylo úřady meziválečného Československa změněno na "Josef“ [interview č. 10, segment \#1-5]). Z tohoto důvodu budeme fenomén osobního jména dále v tomto článku analyzovat na základě rozhovorů s přeživšími holocaustu, kteří byli nacistickým režimem

\footnotetext{
5 V odkazech na rozhovory, $\mathrm{z}$ nichž pochází dané informace či citace, je příjmení anonymizováno. Vzhledem $\mathrm{k}$ tématu tohoto textu však bylo v některých př́ípadech nutné příjmení narátora (at už původní, či současné) „odhalit“.
} 
pronásledováni jakožto „Židé“ (v rozhovorech z VHA vystupují jako „Jewish survivor“, tedy „židovští přeživši“ $).{ }^{6}$ Ačkoliv mohli být v konkrétních jednotlivých př́ípadech lidé podrobeni perzekuci na základě svých dalších identifikací (pohlaví, věk či sociální status), ponecháváme tuto dimenzi v následující analýze stranou.

\section{Jméno v rozhovorech s židovskými přeživšími holocaustu (období 1933-1945)}

\section{Nucená změna jména}

Nucená změna jména, ve VHA označovaná klíčovým slovem „compulsory name changes“, se ve zkoumaném materiálu téměř bez výjimky týká narátorek a narátorů, kteří před vypuknutím druhé světové války žili v nacistickém Německu. V této souvislosti nejčastěji zmiňují dvě jména - „Sara“ a „Israel“. Odkazují tím na tzv. „Druhé nařízení k provedení zákona o změně příjmení a rodných jmen“ vydané v srpnu roku 1938, jedno z předválečných protižidovských opatření [Heim 2008: 269].

Dle tohoto nařízení směla být novorozencům, kteří byli dle tzv. norimberských zákonů z roku 1935 považováni za „Židy“, nadále udělována pouze ta jména, jež byla uvedena ve směrnici vydané ministerstvem vnitra [Heim 2008: 270]. Zbývající osoby „židovské rasy“, jejichž jméno nebylo uvedeno v seznamu „pro Židy př́pustných jmen“, byli povinni si do 1. ledna 1939 přidat ke svému stávajícímu rodnému jménu jméno druhé, v očích nacistických úřadů „typicky židovské“ - pro ženy to bylo jméno „Sara“ a pro muže „Israel“ [Heim 2008: 270]. Tato jména musela být uváděna při každém úředním styku a při nerespektování tohoto nařízení hrozil dotyčným měsíc až půlrok ve vězení [Heim 2008: 270].

Toto opatření narátoři a narátorky vnímali (zcela v souladu s jeho skutečným účelem) jako zpo̊sob, pomocí něhož mohli nacisté „Židy“ snadněji identifikovat [interview č. 46, segment \#38], a to především při oficiálním úředním styku. Pouhý pohled do osobních dokumentů nacistům dle narátorky Rity K. umožňoval zacházet s dotyčnými „jak se jim zachtělo“ [interview č. 55, segment \#231].7 To v praxi mnohým „Sarám“ a „Israelům“ výrazně snižovalo šanci najít si zaměstnání [interview č. 36, segment \#23] či uprchnout ze země. Cestovní pasy „Židü“ byly totiž kromě prostředních „židovských“ jmen doplněny o vytištěné velké písmeno J (dle „Jude“, tj. „Žid“) [interview č. 18, segment \#88]. Majitelé

6 Psaní prvního písmene slova žid/Žid je v češtině komplikované - podle pravidel českého pravopisu by se mělo psát „žid“v případě, kdy máme na mysli náboženský význam (tj. příslušníka židovské náboženské obce, člověka vyznávajícího a praktikujícího judaismus), zatímco psaní „Žid“ je namístě tehdy, jde-li o význam národnostní či etnický (tj. příslušník židovského národa, přívrženec nacionální emancipace Žido̊). Problém je, že v období přelomu 19. a 20. století se oba uvedené významy empiricky překrývají natolik komplexně, že je často obtížné rozhodnout, o jaký případ se jedná. Stejně tak je zápis problematický v citacích z interview: málokdy lze s jistotou vědět, jaký význam měl/a v dané chvíli na mysli pamětník či pamětnice. Různí autoři řeší tento problém různě, včetně duálního zápisu „Ž/žid“ [Hamar 2010]. My sami - s vědomím jistého zjednodušení - v tomto článku konzistentně používáme variantu „Žid/ovka“. Uvozovky používáme, abychom poukázali na skutečnost, že se jedná o osoby označené za Židy na základě Norimberských zákonů, které se nutně tímto zpo̊sobem samy identifikovat nemusely.

7 V této i následujících přímých citacích $\mathrm{z}$ archivních rozhovorů využíváme vlastního překladu z původního jazyka nahrávky. 
takovýchto pasů, prchající před nacistickou perzekucí, nebyli dle tvrzení Evy G. v mnohých zemích vítáni [interview č. 18 , segment \#89]. ${ }^{8}$

Povinné přidělování „typicky židovských jmen“ však kromě znevýhodnění a zviditelnění při úředním styku sloužilo i jinému účelu. Německo-židovský filolog Victor Klemperer, jenž holocaustu unikl díky „árijstvi“ své manželky, si po celé trvání nacistického režimu vedl deník, do něhož zaznamenával své postřehy o tzv. „jazyku Třetí ŕíše“. K „typicky židovským jménům“ uvedl, že „vypadají podivně a minimum mezi nimi je skutečně starozákonní" [Klemperer 2003: 86]. Na seznam Židům povolených jmen se podle něj dostala židovská jména ve tvarech, „která znějí německému uchu dílem trapně, dílem komicky“ [Klemperer 2003: 86]. Tato jména měla dle Klemperera své nositele především zesměšnit [Klemperer 2003: 87]. To ostatně v rozhovoru potvrzuje i Eva H., jež tvrdí, že i prostřední „židovská“ jména „Sara“ a „Israel“ byly nacisty udělována z „podlosti“ [interview č. 19, segment \#29].

Není proto překvapivé, že sotvakdo přijal tato jména doopravdy za svá. „To nebylo moje jméno, “vyjádřila se například Alice C. o jménu „Alice Sara Baruch“, jež stálo v jejím cestovním pase [interview č. 3, segment \#48]. Jakožto dvanáctiletá dívka nechápala nařízení upravující jména „Židü“ ani již citovaná Rita K. [interview č. 55, segment \#232]. Její otec ji však uklidnil tím, že jméno „Sara“ znamená v hebrejštině „princezna“ [interview č. 55, segment \#232].

Na význam jmen „Sara“ a „Israel“ v rozhovorech odkazuje nejedna narátorka nebo narátor, všichni se na něm shodují: „Sara“ dle nich znamená „princezna“ a „Israel“ „boží bojovník“ [interview č. 46, segment \#38]. Tato skutečnost je vzhledem k výše zmiňovaným „typicky židovským jménům“, která byla současníky vnímána jako zesměšňující, pozoruhodná. Zatímco nově narozené části „židovského“ obyvatelstva nacisté přisoudili dehonestující „židovská“ jména, část již narozené populace s „nežidovskými“ jmény obdržela druhé rodné jméno, jež v ženské i mužské variantě (mimo kontext nacistického nařízení) bezpochyby vyvolávalo pozitivní asociace. I přesto je zavádění prostředních jmen nutné vnímat jako předstupeň pozdější „Davidovy hvězdy“, jež „Židy“ veřejně stigmatizovala na každém kroku.

\section{Dobrovolná změna jména}

Nemalá část narátorů či narátorek, kteří byli v předválečném nacistickém Německu či později za války na nacisty okupovaném území označeni a pronásledováni jako „Židé“, přistoupila ke změně svého jména dobrovolně (byt’ byla k tomuto kroku svým zpo̊sobem donucena vnějšími okolnostmi).

Jednu skupinu přeživších holocaustu, kteří si z vlastního popudu změnili své jméno, tvoří emigranti z předválečného nacistického Německa. Ti své německy znějící jméno často přizpůsobili jazyku dominujícímu v místě jejich exilu (např́íklad z „Hannelore“ utíkající se svými rodiči do Belgie se stala „Anne-Laure“ [interview č. 7, segment \#12]). Kromě praktických důvodů, jako byl například problém s výslovností německých jmen

8 Jako př́klad může posloužit i - oficiálně neutrální - Švýcarsko, které již od roku 1938 respektovalo razítkovou politiku nacistického Německa a rozlišovalo mezi uprchlíky „židovskými“ a „nežidovskými“" [Switzerland during...]. 
$\mathrm{v}$ cizojazyčném prostředí, hrála $\mathrm{v}$ takových př́padech významnou roli i snaha o asimilaci v nové společnosti a odstranění veškerých znaků, které by odkazovaly na migrantský původ těchto osob.

Druhou skupinu př̌živších, kteří v rozhovorech popisují svou dobrovolnou změnu jména, představují ti, kteří byli během druhé světové války na základě přisuzovaného „židovského původu“ vystaveni nacistické perzekuci. Jejich hlavní motivací byla ve většině prípadů snaha skrýt svou „židovskost“ odstraněním „židovského“ jména a tím se vymanit z bezprostř̌edního ohrožení života, jemuž byli „Židé“ ze strany nacistů vystaveni. Dotyční si proto volili taková jména, která nebyla vnímána jako „židovská“ a která jim $\mathrm{z}$ toho důvodu umožňovala splynout $\mathrm{s}$ okolním prostředím. Přijetím polsky, francouzsky či italsky znějících jmen se z nacisty perzekvovaných „Židü“ stali př́slušníci nepronásledované většiny, kteří, při notné dávce štěstí, měli šanci uniknout důsledkům tzv. „konečného řešení židovské otázky“.

Skutečnost, že taková, $v$ jistém smyslu, formalita jako je změna jména, některým narátorům a narátorkám de facto zachránila život, je reflektována i ve zkoumaných rozhovorech. „Otec nám zachránil život, jinak bychom skončili v Osvětimi, “ konstatuje Gustav B., jehož otec spolu s celou rodinou přijal přímení svého polského dědečka a tím sebe i své bližní zachránil před deportací do vyhlazovacího tábora [interview č. 23, segment \#6]. „A díky tomu jsme, “ zakončuje vyprávění o obstarávání „nežidovských“ osobních dokumentů s falešnými prríjmeními Elizabeth E., „zůstaly naživu“ [interview č. 14, segment \#45].

Právě se zařizováním falešných osobních dokladů je dobrovolná změna jména ve zkoumaných interview spojována nejčastěji. Získání dokladu, který by neobsahoval úřední záznam o „židovské př́slušnosti“ jeho vlastníka, bylo nezbytností pro všechny, kteří se za války před nacistickou perzekucí ukrývali či byli na útěku. $S$ „nežidovským“ dokladem totiž, dle dobového vnímání některých narátorek a narátorů, dotyčný „Židem“ být přestával: „Vystoupila jsem z vlaku [s doklady své kamarádky - „Nežidovky“] a už jsem nebyla Židovka“ [interview č. 17, segment \#159]. Vlastnictví takového dokumentu proto mohlo představovat víceméně spolehlivou záruku pro přežití války: „Když někdo přišel a vyptával se, měli jsme čím doložit, že nejsme Židé“ [interview č. 14, segment \#45].

Většina zkoumaných rozhovorů nepodává vysvětlení, jak vydávání falešných dokladů konkrétně probíhalo. Velká část narátorů a narátorek jednoduše konstatuje, že si falešné dokumenty „obstarali“" „sehnali“ či že je od někoho „dostali“ [interview č. 15, segment \#11; interview č. 28, segment \#23; interview č. 45, segment \#29]. Paul L. nicméně upozorňuje na skutečnost (a vyprávění ostatních ji potvrzují), že za války existovaly „falešné doklady a pravé falešné doklady: falešné doklady jsou jednoduše falešné. Ale pravé falešné doklady jsou doklady, které jsou falešné proto, že nejsou vaše, a jsou pravé proto, že někdo někde takové jméno doopravdy má“ [interview č. 45, segment \#28]. Zřejmě kvưli nedostatečné věrohodnosti falešných dokladů („Tehdy jsem nemohla chodit ven, protože jsem neměla dobré doklady. [...] Když se pas podržel proti světlu, viděli jste, že je zfalšovanýc [interview č. 39, segment \#22]) si většina narátorů a narátorek opatřovala dokumenty, jež byly vydané oficiálními úřady, tedy dle výše zmíněné kategorizace tzv. „pravé falešné doklady“.

Tyto doklady dotyční získávali různými způsoby. Svou vlastní „Kennkarte“ [interview č. 42, segment \#71] bez stigmatizujícího J označujíćího „Židy“ [interview č. 45, segment \#29], a tím i relativní záruku bezpečí, jim věnovali blízcí přátelé [interview č. 39, segment 
\#16] i neznámí lidé [interview č. 6, segment \#14]. Osobní doklady skutečných lidí si někteří přeživší přisvojili například poté, co je našli odhozené polským vojákem [interview č. 31, segment \#7] či v sutinách vybombardované školy [interview č. 44, segment \#88]. Ve všech případech se však vydávali za někoho, kdo pod daným jménem, at už současně či v minulosti, vystupoval.

Jakousi „hybridni“ podobu skutečných falešných dokladů představovaly dokumenty, které byly narátorkám a narátorům vystaveny na základě rodného listu zemřelé osoby (většinou dítěte) [interview č. 38, segment \#10]. Takové dokumenty, obzvláště pokud byly doplněny o fotografii, podpis a otisky prstů svého nového majitele [interview č. 15, segment \#33], poskytovaly přeživším relativně bezpečné krytí před nacistickou perzekucí.

\section{Ztráta jména a přidělení vězeňského čísla}

Skrývat se pod falešným jménem až do konce války se ovšem podařilo jen malé části citovaných narátorek a narátorů. Velká část z nich byla nakonec deportována do nacistických koncentračních táborů. Zde na jejich falešném ani skutečném jménu nezáleželo vězni koncentračních táborů se totiž na tomto místě již stávali „bezejmennými“.

V rámci systému fungování nacistických koncentračních táborů bylo každému vězni při vstupní registraci přiděleno identifikační číslo [interview č. 5, segment \#67], jímž byl od dané chvíle oslovován [interview č. 1, segment \#76]. Osobní jméno, které vězně spojovalo s životem před internací, tak ztrácelo svůj význam [interview č. 25, segment \#150-152].

Přidělování identifikačních čísel ovšem nesloužilo pouze účelům táborové byrokracie. Celá přijímací ceremonie, při níž byli nově příchozí postupně zbaveni dosavadního života, majetku, důstojnosti i vnějšího vzhledu, měla totiž vést $\mathrm{k}$ „otřesení člověka v jeho základních pozicích“, přičemž finální ztráta jména představovala „nejhlubší zmrzačení vlastního já“ [Sofsky 2006: 94-95]. Ztrátou jména zároveň započal konec dosavadní životní historie, která byla s tímto jménem spjata [Sofsky 2006: 94]. Jedinec se stal v koncentračním táboře pouhým anonymním číslem mezi tisíci ostatními.

O své zkušenosti „občanské smrti“ [Sofsky 2006: 95] při přidělení vězeňského čísla podává svědectví např́klad Siegi I.: „Ze všeho nejdřív jsme ztratili svá jména - už jsme nebyli jedinci, stali jsme se čísly. [...] Řekli nám, že už nejsme lidskými bytostmi a že jsme podlidé a jako s takovými se s námi bude zacházet“ [interview č. 52, segment \#30]. Důsledky přidělení vězeňského čísla v rozhovoru popisuje i Harold G.: „Od té chvíle už na jménech nezáleželo, “ vězni se podle něj stali „mrtvými čísly“ [interview č. 25, segment \#150-152].

I přes traumatizující zkušenost, již přidělení identifikačního čísla představovalo, vězňům $\mathrm{v}$ prostředí koncentračního tábora nezbývalo nic jiného, než tuto novou identitu přijmout a její přijetí navíc dennodenně demonstrovat při sčítání vězňů na „apelplacu“ [interview č. 33, segment \#92]. Proto bylo nezbytně nutné, aby si každý vězeň své číslo (v jeho německém znění) zapamatoval a byl schopen ho vyslovit či na něj reagovat [interview č. 34, segment \#43]. V jiném případě ho totiž mohl stihnout př́sný trest dozorců [interview č. 33, segment \#93]. Skutečnost, že si většina přeživších své číslo z koncentračního tábora (většinou v němčině) stále pamatuje [interview č. 5, segment \#68], lze vysvětlit právě extrémními podmínkami internace, které jednotlivce k přijetí této nevlastní identity přinutily. 
Dehumanizačnímu rozměru přidělení vězeňského čísla je však v rozporu s významem, jenž mu připisuje citovaný sociolog Sofsky, ve zkoumaných rozhovorech věnováno překvapivě málo pozornosti. V některých případech se zdá, a to především u žen, že tím „nejhlubším zmrzačením vlastního já“ nutně nemusela být ztráta jména, ale jiná součást přijímacího procesu - například nucené vysvlečení před nastoupenými esesmany [interview č. 30, segment \#48] či ostř́íhání vlasů [interview č. 53, segment \#51]. Toto zjištění zároveň poukazuje na intersekcionální povahu některých zkušeností a prožitků přeživších šoa, tedy na skutečnost, že určité diskriminační a ponižující praktiky mohly nabývat odlišné formy s ohledem na genderovou identitu.

Úvahy o souvislostech ztráty jména se ztrátou lidské důstojnosti můžeme spíše než v orálněhistorických rozhovorech najít v jiném formátu vzpomínání přeživších holocaustu, a to $v$ memoárové literatuře. Příkladem za všechny budiž následující pasáž z autobiografického díla italského spisovatele Primo Leviho Je-li toto člověk:

Je to Null Achtzehn. Jinak mu tady neřeknou, Nula Osmnáct, poslední tři číslovky jeho poznávacího čísla. Jako by si všichni uvědomili, že jenom člověk je hoden jména a že Null Achtzehn už není člověk. Myslím, že sám své jméno zapomněl, nebo se tak alespoň chová. Když mluví, když se dívá, vypadá, jako by byl uvnitř prázdný, jako by už nebyl nic než obal, jako slupičky, prázdné krunýře brouků na břehu rybníka, připoutané jediným vláknem ke kameni a zmítané větrem. [Levi 1995: 43]

Bližší pohled do fungování koncentračního tábora Osvětim, líčený Levim, zároveň poukazuje na skutečnost, že vězeňská čísla ve výsledku nebyla tak anonymizující, jak by se při pohledu na řadu čísel a písmen mohlo zdát: „Táborovým mazákům číslo prozradí všechno: dobu příchodu do tábora, transport, ve kterém dotyčný přijel, národnost“ [Levi 1995: 27]. Vzhledem k možnosti odvozovat od vězeňských čísel např́klad původ jeho nositele („Všichni vědí, že sto sedmdesát čtyři tisíc jsou italští Židé“ [Levi 1995: 50]) lze konstatovat, že i vězeňské číslo mohlo v kontextu koncentračního tábora vypovídat o etnické, sociální či politické příslušnosti podobně jako běžné jméno [Knappová 1989: 78; Finch 2008].

\section{Vytetovaná identita}

„Naučil jsem se, že jsem häftling. Jmenuji se 174 517; pokřtili nás a až do konce života budeme mít na levé ruce vytetované znamení [Levi 1995: 27]. Kromě ztráty jména, jíž byla věnována pozornost v předchozí sekci, zde již citovaný spisovatel Primo Levi odkazuje na další součást přijímací procedury, jež byla prováděna pouze v koncentračním táboře Osvětim - vytetování vězeňského identifikačního čísla na levé předloktí příchozího [Kogon 1974: 50]. Vzhledem k tomu, jak často se ve zkoumaných rozhovorech vězeňské tetování zmiňuje, a rovněž s ohledem na jeho úzkou spojitost se ztrátou osobního jména, potažmo udělením nové identity vězně, odbočíme v této sekci k vytetovaným identifikačních číslům na rukou vězňů.

Jak bylo výše zmíněno, nahrazení osobního jména vězeňským číslem představovalo $\mathrm{v}$ nacistických koncentračních táborech násilné přidělení nové sociální identity (identity vězně v táboře). Vězeňské tetování, jež mělo oficiálně sloužit k snazšímu rozeznávání těl zemřelých jedinců i identifikaci vězně při případném pokusu o útěk [Tattoos and 
Numbers...], lze proto vnímat jako fyzické propojení vězňova těla s touto identitou a zároveň jako její „Zvěčněni“ [Levi 1995: 27]. Identita vězně stvrzená vytetovaným identifikačním číslem byla totiž vzhledem k charakteru tetování definitivní - nacisté nepřipouštěli, že by se vězeň kdy mohl stát „někým jiným“. Identifikační číslo bylo přitom udělováno pouze těm, kteří nebyli odsouzeni k okamžité smrti v plynových komorách [interview č. 35, segment \#233], nýbrž k pomalé a postupné „likvidaci prací“ [Herbert - Orth - Dieckmann 2002: 720], již měli v táboře vykonávat [interview č. 9, segment \#78].

Pro narátorky a narátory analyzovaných orálněhistorických interview se však identita vězně, vytetovaná na jejich předloktí, nakonec nestala jejich identitou definitivní, ale základem pro více či méně přijímanou sociální identitu „přeživšího holocaustu“. 9 Zřejmě proto je vězeňskému tetování ve zkoumaném materiálu věnována poměrně velká pozornost. Narátoři jsou př́i popisu př́jezdu do tábora často dotazováni, zda byli také tetováni [interview č. 51, segment \#27]. V prŕípadě, že narátor/ka své tetování z koncentračního tábora stále má, je zpravidla vzápětí vyzván/a, aby jej ukázal/a na kameru [interview č. 2, segment \#69] a nahlas přčctl/a [interview č. 8, segment \#20]. Detailní záběry na vypravěčovo předloktí s vytetovaným číslem bývají mnohdy součástí závěrečných scén rozhovorů, při nichž narátoři a narátorky komentují své osobní dokumenty, předměty či fotografie. Do obsahu těchto pasáží často výrazně zasahuje osoba tazatele či tazatelky [interview č. 9, segment \#79], jejíž pokyny mohou v některých případech vést až $\mathrm{k}$ jisté schematičnosti těchto záběrů [interview č. 1, segment \#76].

Frekvenci tématu vězeňského tetování v analyzovaných rozhovorech mapuje i klíčové slovo „odstranění vězeňského tetování“ („prisoner tattoo removal“). V těchto sekvencích narátorky a narátoři objasňují své pohnutky k odstranění, či naopak ponechání tetování z Osvětimi, čímž zároveň částečně poodhalují i svůj postoj k identitě „přeživší/ho holocaustu“, jež se na tetování váže. Skupinu dotazovaných lze celkem logicky rozdělit na ty, kteř́ si tetování po válce nechali odstranit, a na ty, kteří si jej ponechali.

Není př́liš překvapivé, že jedním z motivů k odstranění vytetovaného vězeňského čísla byly traumatizující vzpomínky, jež si narátoři a narátorky s tetováním spojovali [interview č. 20, segment \#23]. Odstranění čísla z Osvětimi pro některé přeživší představovalo pomyslnou tlustou čáru za traumatickou minulostí a počátek nového života [interview č. 53, segment \#50] či čistě kosmetický zákrok motivovaný negativním postojem k jakémukoli tetování [interview č. 43, segment \#134]. V některých případech byli přeživší k operativnímu odstranění vězeňského čísla přinuceni vnějšími okolnostmi, jako například Hans A. prri nástupu do americké armády [interview č. 23, segment \#17] či Doris D. poté, co se jí do tetování dostala infekce [interview č. 12, segment \#51]. Častým popudem ke zbavení se osvětimského stigmatu byla také snaha vyhnout se zvídavým pohledům a otázkám [interview č. 21, segment \#82] či ne vždy prŕijemným projevům soucitu [interview č. 13, segment \#148] blízkých i cizích lidí.

Množství záběrů na vybledlá vytetovaná čísla, které lze ve zkoumaných interview najít, dokazuje, že potřeba zbavit se tetování z Osvětimi se týkala jen určité části přeživších šoa. Pro ty, kteří si tetování po válce ponechali, se totiž vězeňské číslo stalo jakýmsi na první pohled viditelným mementem holocaustu, jež z levého předloktí promlouvá ke svým

9 Viz klíčové slovo „survivor identity“ ve VHA. 
nositelům i jejich okolí. Pro některé narátor(k)y nabylo vytetované číslo po válce osobního významu a představovalo jakési varování [interview č. 9, segment \#78] či připomínku během šoa zahynuvších příbuzných [interview č. 32, segment \#70]. Jiní vnímali své osvětimské tetování naopak jako připomínku holocaustu [interview č. 56, segment \#46], s níž by mělo být konfrontováno především jejich okolí: „Schovávat číslo? Nikdy. [...] Lidem se musí připomínat, že se takové věci staly, “ domnívá se např́iklad narátorka Liselotte I. [interview č. 35, segment \#210].

\section{Jméno v rozhovorech s židovskými přeživšími holocaustu (po roce 1945)}

\section{Nucená změna jména}

Takřka všechny rozhovory, které jsou ve VHA označeny klíčovým slovem „compulsory name changes“, se týkají protižidovského nacistického opatření, jemuž byla věnována pozornost $\mathrm{v}$ jedné $\mathrm{z}$ předchozích sekcí. Doklady o změně jména, $\mathrm{k}$ níž by byli přeživší šoa donuceni po roce 1945, jsou proto ve zkoumaném materiálu spíše ojedinělé. Okolnosti, které narátory a narátorky ke změně jména i přes jejich vůli donutily, jsou přesto hodné naší pozornosti.

$\mathrm{Na}$ rozdíl od zmiňovaného nacistického nařízení o změně jména u osob označených za „Židy“ z rozhovorů nevyplývá, kdo konkrétně změnu jména po roce 1945 nařizoval, či zda byla tato opatření jakkoli právně ukotvena: „Donutili nás změnit naše jména,“ popisuje neurčitě situaci v poválečném Polsku židovská přeživší Andreé A. [interview č. 4, segment \#33]. Nátlak na změnu jména ze strany nadřízených, jenž se zřejmě neopíral o žádný právní základ a jenž byl navíc spojený s protižidovskými resentimenty, pocítil také manžel Sary H.-H. v poválečném Rumunsku: „Chtěli, aby si změnil jméno“ [interview č. 50, segment \#228]. Odpor manžela narátorky vůči nucené změně jména byl natolik silný, že se raději rozhodl se svou ženou emigrovat [interview č. 50, segment \#230].

Ve srovnání s nacistickým opatřením z roku 1938 neměla tato vynucená změna jména „židovskost“ svých nositelů zvýraznit, ale naopak ji skrýt, slovy narátorky Andreé A.: „V̌̌ichni museli být Poláky, a proto i jména musela být polská“ [interview č. 4, segment \#34]. Lze předpokládat, že se ve výše jmenovaných př́padech mohlo jednat o svévoli úrudů či jednotlivých osob motivovanou dobovou společenskou atmosférou, v níž panovala snaha o vytvoření národnostně „čistých“ státních celků [srov. Ther - Siljak 2001].

Tlak na asimilaci skrze změnu jména, jak ze zkoumaných rozhovorů dále vyplývá, nebyl po válce př́tomný pouze v Evropě, ale např́iklad i v Izraeli a USA. John H., jenž po roce 1945 nastoupil do pozice izraelského velvyslance v Etiopii, byl dle izraelských předpisů povinen přijmout jméno „Hannan Haenosh“, tedy hebrejský ekvivalent svého původního jména [interview č. 29, segment \#2]. Narátorku Glorii L. k přijetí nového jména nepřinutily úřady či předpisy, ale její vlastní teta, která náctiletou přeživší šoa po poválečné emigraci do Spojených států vychovávala. Př́ibuzná narátorky se domnívala, že teprve přijetím jména „Gloria“ se její neteř „stane Američankou“ [interview č. 22, segment \#259]. I přes počáteční odpor, který narátorka $\mathrm{k}$ „americkému“ jménu pocitovala [interview č. 22, segment \#260], si na nové jméno postupem času zvykla [interview č. 22, segment \#266]. 


\section{Dobrovolná změna jména}

Rok 1945 se stal jakýmsi „bodem nula“ nejen v evropských dějinách, ale zcela pochopitelně i v životech přeživších holocaustu. Není proto divu, že se někteří z nich rozhodli tento nový začátek stvrdit i změnou svého jména. To platilo především pro přeživší, kteří se rozhodli po roce 1945 emigrovat a začít znovu v jiné zemi. Podobně jako předváleční emigranti uzpůsobovali své rodné jméno, jehož výslovnost novým spoluobčanům činila obtíže, místnímu jazyku i zvyklostem [interview č. 26, segment \#3].

Část přeživších, jež za války vystupovala pod falešným jménem, se jednoduše, „hned jakmile to bylo možné, vrátila ke svému rodnému jménu, protože jedině to dotyční považovali za jméno, které jim náleží [interview č. 23, segment \#99]. Představa návratu k rodnému, „německému“, jménu byla pro některé přeživší naopak nepřijatelná. Traumatizující prožitky z válečných let v mnohých vytvořily jakýsi „odpor vůči Němcům“, jenž se mohl přenést i na vlastní německy znějící jméno a ve výsledku tak vést $k$ jeho změně [interview č. 47, segment \#2]. Dle Petera A., jenž si po vzoru otce, bývalého vězně z Mauthausenu, změnil své rodné př́ímení z „Altmann“ na madarizované „Abonyi“, se přinejmenším v Mad’arsku jednalo o poměrně rozšířenou praxi [interview č. 47, segment \#2].

Skutečnost, že se zmiňovaný „odpor vưči Němcům“ netýkal pouze jednotlivců, ale celé poválečné evropské společnosti, dokládá v rozhovoru Emery G. (čímž zároveň vysvětluje vlastní popud k poválečné změně jména): „Po válce nebylo dobré mít německé jméno“ [interview č. 16, segment \#119]. Na tom, že „nebylo dobré mít [ani] židovské jméno“ se ve svých životopisných vyprávěních shoduje velký počet narátorek a narátorů.

Právě poválečný antisemitismus, jenž panoval v mnoha evropských státech [Králová - Kubátová 2016], byl totiž ve zkoumaných rozhovorech jednou z nejčastějších příčin dobrovolné změny jména. Michael $O$., podle něhož byly protižidovské nálady po válce „ještě horši“ než před válkou, dobový antisemitismus přirovnal k ,jedu, který po sobě Hitler v Evropě zanechal“ [interview č. 41, segment \#241]. Zvěsti o protižidovských pogromech, v něž tento „jed“ v poválečném Polsku vyústil, některé přeživší přiměly k tomu, aby si své jméno, okolím vnímané jako „židovské“, popolštili [interview č. 48, segment \#118]. Mnohým se za takové situace zdálo zkrátka jednodušší žít s „polským“ jménem [interview č. 11, segment \#69].

Pro život pod jménem, jež by svého nositele nestigmatizovalo jako „Žida“ či „Židovku“, se tedy někteří přeživší rozhodli víceméně i z pragmatických důvodů, a to nejen v poválečném Polsku. Rudolf S. se například ze „Schlesingera“ stal česky znějícím „Slezákem“ poté, co ze zkoušky, kterou se chystal složit, bylo vyhozeno nápadně mnoho uchazečů s „židovskými“ jmény [interview č. 49, segment \#21]. Michael O. se zase domníval, že se v poválečné Belgii s polsky znějícím příjmením „posune někam dál“ [interview č. 41, segment \#241]. Henry N., jenž od roku 1939 žil v emigraci v USA, se v 50. letech rozhodl pro změnu příjmení proto, že mu připadalo „trapné“, že se představoval jiným příjmením než jeho bratr. Ten si totiž své příjmení změnil na „Norton“ již dříve, zatímco Henry zůstal u původního jména „Nussenbaum“ [interview č. 27, segment \#37]. Vzhledem k právnické profesi obou bratrů je pravděpodobné, že tento narátor změnou svého jména sledoval především vytvoření důvěryhodnější image u svých klientů. 


\section{Navrácení ztracených jmen}

V jedné z předchozích sekcí, věnujících se fenoménu jména u přeživších holocaustu v letech 1933-1945, jsme se zaměřili na ztrátu jména, kterou prodělali všichni vězni nacistických koncentračních táborů. Na rozdíl od nucené či dobrovolné změny jména však tento jev, ze zjevných důvodů, nelze sledovat v období poválečném. Po roce 1945 nicméně takřka po celém světě dochází ke komemorativním aktivitám, které na ztrátu jména bezprostředně reagují a jejichž středobodem jsou právě jména obětí šoa.

Ve snaze zdůraznit těžko představitelný rozsah tragédie holocaustu sklouzávala v minulosti nejen historiografie, ale také oficiální připomínka nacistické genocidy k nekonečným výčtům obětí, odpravených transportů či zplynovaných osob. Mnozí přeživší šoa tuto praxi nehodnotili zcela pozitivně [interview č. 40, segment \#103]. Znepokojení nad anonymitou čísel proto vedlo od 80. let 20. století (především v západoevropských zemích) ke vzniku četných pamětních knih připomínající osudy konkrétních lidí [Příspěvek $k$ dějinám...]. V českém prostředí se takovým počinem stala Terezínská pamětní kniha, jež vznikla z iniciativy citované narátorky Margity K. a jejího manžela Miroslava. Pamětní kniha, jež vyšla ve dvou dílech v průběhu 90. let, mapuje osudy Židů deportovaných v letech 1941-1945 z Čech a Moravy. Početný tým autorů si při práci na Terezínské pamětní knize kladl za cíl „dát a vrátit těmhletěm ta jména, tu totožnost, “ [interview č. 40, segment \#104] a tím dokázat, „že každý z těch šesti milionů zavražděných židovských mužů, žen a dětí byl člověk, lidská bytost se jménem, s nezadatelným právem na život a lidskou důstojnost“ [Havel-Kárný 1995: 13].

Postupem času se však ukázalo, jak v rozhovoru zmiňuje spoluautorka knihy Margita K., že sestavování jmenných seznamů v podobných publikacích zbavovalo čísla „znevažující anonymity“ [Př́spěvek k dějinám...] jen do určité míry: „Věděli jsme (...) že i když je to krásně přehledný, (...) že to je vlastně jenom seznam a nic víc“ [interview č. 40, segment \#104]. $\mathrm{Z}$ toho důvodu se nakonec tým kolem Terezínské pamětní knihy rozhodl uvádět jména deportovaných českých Židů dle vypravených transportů [interview č. 40, segment \#104]. Vydělením přeživších od těch, kteří během transportu či následné internace v koncentračních táborech zahynuli, chtěli znázornit „tu celou hrůzu“ [interview č. 40, segment \#104].

Vedle pamětních knih představují další způsob symbolického navracení jmen obětem šoa například veřejná čtení jmen. V českém prostředí se jedná o každoroční celorepublikovou událost „Jom Ha-Šoa“ pořádanou Institutem Terezínské iniciativy. Prostřednictvím „maratonu čtení jmen žen, mužů a dětí, kteří byli kvůli svému přisouzenému židovskému nebo romskému původu pronásledováni, perzekvováni a zavražděni během druhé světové války“ mají být dotyční navráceni do společné paměti [Jom ha-šoa...]. Ztrátu lidství $\mathrm{v}$ důsledku přidělení vězeňského čísla tematizovaly i nedávné oslavy osvobození koncentračního tábora Mauthausen s názvem „Nikdy číslem. Vždy člověkem“ [Fest der Freude...].

Ústřední roli jmen při komemoraci obětí holocaustu dokládá i jejich přítomnost v muzeích a památnících. Kromě tzv. „knih mrtvých“, které jsou součástí většiny památníků v bývalých koncentračních táborech a které zároveň slouží i badatelským účelům, ${ }^{10}$ se jedná o vizuálně působivé znázornění jmen, jež jejich tragicky zahynulým nositelům

10 Např́klad „kniha mrtvých“ se jmény obětí koncentračního tábora Sachsenhausen je přístupná jak v expozici památníku, tak v digitalizované podobě online [Totenbuch KZ...]. 
zajištují věčnou památku na veřejných místech. K takovému druhu hromadného a veřejného navrácení jmen se řadí např́iklad „Hall of Names“v památníku Jad vašem [Hall of Names...] či v českém kontextu stěny pražské Pinkasovy synagogy s 77297 jmény českých a moravských Židů, kteří se stali obětí šoa [Havel - Kárný 1995: 13].

Jako další příklad „de-anonymizace“ obětí šoa ve veřejném prostoru uvádíme známý projekt německého umělce Guntera Demniga, jenž se za několik let své existence rozšířil takřka po celé Evropě. Projekt „Stolpersteine“, jenž se do češtiny (poněkud nepřesně) překládá jako tzv. „kameny zmizelých“ [Židovská obec Brno - Stolpersteine], spočívá v umistování mosazných dlažebních kostek v místech posledního bydliště osob, které byly pronásledovány a zavražděny nacistickým režimem [START: STOLPERSTEINE]. V duchu motta Demnigova projektu, převzatého z talmudu, „člověk je zapomenut teprve tehdy, je-li zapomenuto jeho jméno“ [START: STOLPERSTEINE], jsou na kostkách vyryta jména, data narození, deportace a smrti obětí nacismu. Náhodný kolemjdoucí, jenž má o tyto kameny pomyslně „zakopnout“, si díky těmto nevšedním dlažebním kostkám může tragédii šoa spojit nejen s konkrétními místy, ale především s konkrétními lidmi, jejichž jména jsou na mosazné kostce zvěčněna.

Všechny zmiňované, pro ilustraci vybrané příklady vzpomínkových praktik naznačují, že uctění obětí na základě navrácení jejich jména se jeví jako jeden z nejrozšířenějších způsobů oficiální komemorace holocaustu. Navrácení jména, jež je vnímáno jako připomenutí a uctění celé osobnosti jeho nositele, má v tomto kontextu ústřední význam. V tomto ohledu se připomínání holocaustu podobá reflexi dalších případů „kategoriálního vražděni“ (jak holocaust označil Zygmunt Bauman [2010: 8]), jako je například Montrealský masakr, při kterém bylo v roce 1989 zavražděno 14 studentek inženýrství na Univerzitě v Montrealu, a to právě - jen a pouze - proto, že se jednalo o ženy studující „mužský“ obor (a v očích vraha tedy o „feministky“, které nenáviděl). Jak píší na samém počátku své knihy o této tragické události sociologové Peter Eglin a Stephen Hester:

Když byly Geneviève Bergeron, Hélène Colgan, Nathalie Croteau, Barbara Daigneault, Anne-Marie Edward, Maud Haviernick, Barbara Maria Klucznik, Maryse Laganière, Maryse Leclair, Anne-Marie Lemay, Sonia Pelletier, Michèle Richard, Annie St-Arneault a Annie Turcotte 6. prosince 1989 zastřeleny Marcem Lépinem, nebyly zavražděny jako osoby s určitými jmény. Zemřely, protože byly považovány za zástupce kategorie: feministky. Odezva na tyto vraždy proto zčásti spočívala v navrácení identit obětí jako konkrétních osob s jedinečnými životy, namísto jejich př́slušnosti k nějaké kategorii. [Eglin - Hester 2003: vii]

\section{Závěr}

Tento článek představil okolnosti, za nichž židovští přeživší holocaustu dostávali či si sami volili nová jména, o svá jména přicházeli a jména zemřelým bližním vraceli. Jaká zjištění o proměnách a významu jména jakožto atributu identity $\mathrm{z}$ analyzovaných rozhovorů $s$ přeživšími šoa vyplývají?

At už šlo o nacistický zákaz pojmenovávat židovské děti „německými“ jmény, či o poválečný tlak na eliminaci „židovských“ a „německých“ jmen v osvobozených národních státech, válečná i poválečná společnost měla tendenci vnímat jméno a identitu jako neoddělitelnou dvojjedinost, která na sebe navzájem působila. Pro nacionální socialisty platilo, že kdo měl „židovské“ jméno, musel nutně „být Židem“, a naopak: kdo „byl Židem“, musel se 
také „židovsky“ jmenovat. Pro poválečnou společnost naopak platilo, že „německé“ jméno má pouze „Němec“, což v dobovém vnímání často znamenalo „nacista“. A polský či český národ měl být po válce posílen tím, že se z občanů s „židovským“ jménem stali „Poláci“ a „Češi“ s odpovídajícími „polskými“ a „českými“ jmény.

Z vyprávění velké části narátorek a narátorů překvapivě vyplývá, že ztrátu vlastního jména a degradaci na číslo v koncentračním táboře nevnímali jako zvláště traumatizující zážitek. Ztráta jména jakožto ztráta lidství je spíše tematizována v odborné a memoárové literatuře, která má od táborové reality v prvním př́ípadě emocionální, v druhém případě časový odstup. Ten umožňuje reflektovat poměrně abstraktní pojem jako je jméno jakožto nositel lidství. Naproti tomu však narátor či narátorka v rámci orálněhistorického interview znovuprožívá veškerou táborovou každodennost, a tudíž se při vyprávění většinou zaměřuje spíše na fyzické utrpení, jakým bylo bití, hladovění a vysilující práce. Vyvstává i otázka, do jaké míry se v tomto napětí odráží samotná komemorativní forma, ve které je narativ produkován. Zdá se, jako by situace orálněhistorického interview díky fyzické spolupřítomnosti dvou osob snáze umožňovala otevírat reflexi tělesných prožitků, zatímco psané texty směřují k orientaci na reflexi kulturních aspektů prožitého násilí.

U přeživších koncentračního tábora $\mathrm{v}$ Osvětimi ještě přibývá další téma, kterým je vězeňské číslo vytetované na předloktí. K tomuto zásahu do své tělesné integrity po válce zaujali rozdílné postoje, týkající se např́iklad odstranění či naopak ponechání tohoto stigmatu, a tyto postoje lze chápat jako další $\mathrm{z}$ atributů sociální identity přeživší/ho holocaustu. Podobně jako žlutá hvězda, i tetování na předloktí se postupem času stalo významným kulturním symbolem, jenž je obecně rozpoznatelný jako reprezentace holocaustu. Dokládá to i expozice United States Holocaust Memorial Museum, do níž jsou zařazeny i detailní snímky předloktí přeživších [Portion of photo mural...].

Velký význam má jméno pro ty, kteří se vlastním jménem již představit nemohou. Jejich život skončil v momentu, kdy byli společensky degradováni na číslo v koncentračním táboře určené $\mathrm{k}$ „likvidaci“. Na rozdíl od těch, kteří se $\mathrm{z}$ „táborů smrti“ dostali živí a mohli začít nový život, at už pod svým starým či nově zvoleným jménem, oběti holocaustu zemřely jako bezejmenná čísla. Dominantní přítomnost jmen obětí v různých podobách oficiálního připomínání událostí šoa dokládá, že symbolickému navrácení jmen je při komemoraci holocaustu přikládán velký význam.

V jedné z úvodních částí článku jsme vymezili dvě formy identity prostřednictvím termínů „vlastní a „nevlastní identita. Naše analýza orálněhistorických rozhovorů ukazuje, že i nucená změna jména, tedy atribut nevlastní identity připsané zvnějšku, se v poválečném období postupem času může stát součástí vlastní osobní identity a příslušní narátoři nové jméno nakonec přijímají za své. Stejně tak může být jako součást vlastní identity přijato i vězeňské číslo. Změna jména je odrazem napětí mezi vlastní a nevlastní identitou, které se jako takové však stává nedílnou součástí vyprávěného životního př́iběhu. Způsob, jakým k této změně osobní identity jednotlivé narátorky a narátoři přistupují, je samozřejmě individuální; někdy jde o čistě formální záležitost, které není připisován větší význam, jindy se může jednat o silně traumatizující prožitek. Sociální identita přeživší/ho holocaustu se rovněž do jisté míry překrývá s kolektivní identitou „židovskou“: jde mnohdy opět o přijetí dříve nevlastní, připsané a nezřídka vnucené identity; jak se stručně vyjádřil i Primo Levi v rozhovoru s M. Belpolitim: „Žida ze mě udělali“ [Belpoliti 2003: 215]. 
Náš článek je i z důvodu jeho rozsahu třeba chápat jen jako jakýsi přehled souvislostí, v nichž sociální fenomén jména jako aspektu identity vystupuje v životních př́ibězích židovských přeživších holocaustu. Otázka jména, jeho změny, ztráty a především navrácení se totiž v kontextu holocaustu jeví jako velmi komplexní téma, zvláště když vezmeme do úvahy i související fenomény jako je význam jména v komemorativních aktivitách nebo vězeňské tetování. Zároveň je třeba zdůraznit, že jméno je i v současnosti důležitým a mnohdy rozhodujícím indikátorem etnické či sociální př́ílušnosti. „Pouhé“ jméno tak často může ovlivnit např. rozhodnutí o tom, zda bude dotyčným osobám pronajat byt či zda budou přijaty do zaměstnání, jak ukazují studie z německého i českého prostředí [např. Wir müssen draußen bleiben...; Bartoš - Bauer - Chytilová - Matějka 2013]. Právě na základě křestního jména jako atributu identity se nedávno pokusila německá politická strana Alternativa pro Německo (AfD) prokázat etnickou př́slušnost pachatelů násilných činů v Sársku. Výsledky však ukázaly, že nejčastějšími křestními jmény pachatelů jsou Michael, Daniel a Andreas [AfD-Anfrage im Saarland...]. Je tedy zřejmé, že společenský význam jména a diskriminace na základě jména nemusí být jen tématem historicky orientovaného bádání, jak tomu bylo v tomto textu, ale zůstává dodnes aktuální záležitostí.

\section{Zdroje}

\section{Interview z Archivu vizuální historie USC Shoah Foundation:}

[1] Abram A., ID číslo 54600, Archiv vizuální historie USC Shoah Foundation zpř́stupněný v Centru vizuální historie Malach př̀ Univerzitě Karlově v Praze s podporou infrastruktury LM2015071 LINDAT/Clarin (dále jen VHA).

[2] Albert C., ID 53965, VHA.

[3] Alice C., ID 52543, VHA.

[4] Andreé A., ID 54120, VHA.

[5] Andrew W., ID 54540, VHA.

[6] Anna H., ID 4077, VHA.

[7] Anne-Laure L., ID 54693, VHA.

[8] Bernat R. ID 41915, VHA.

[9] Berry D., ID 53574, VHA.

[10] Charles D., ID 26323, VHA.

[11] David R., ID 54356, VHA.

[12] Doris D., ID 24141, VHA.

[13] Elizabet B., ID 37905, VHA.

[14] Elizabeth E., ID 20800, VHA.

[15] Elizabeth H., ID 42426, VHA.

[16] Emery G., ID 55113, VHA.

[17] Esther K., ID 53019, VHA.

[18] Eva G., ID 52605, VHA.

[19] Eva H., ID 55130, VHA.

[20] Frida L. ID 6660, VHA.

[21] Gerald R., ID 53105, VHA.

[22] Gloria L., ID 53626, VHA. 
[23] Gustav B., ID 55085, VHA.

[24] Hans A., ID 53075, VHA.

[25] Harold G., ID 52452, VHA.

[26] Harry J., ID 55632, VHA.

[27] Henry N., ID 55644, VHA.

[28] Jan R., ID 54348, VHA.

[29] John H., ID 55131, VHA.

[30] Judith L., ID 10827, VHA.

[31] Kazimielz A., ID 54480, VHA.

[32] Lena H., ID 55046, VHA.

[33] Leo K., ID 25932, VHA.

[34] Leon B., ID 52997, VHA.

[35] Liselotte I., ID 52647, VHA.

[36] Louis G., ID 54112, VHA.

[37] Mark N., ID 21334, VHA

[38] Martin M., ID 27728, VHA.

[39] Mathilde S., ID 54318, VHA.

[40] Margita K., ID 12522, VHA.

[41] Michael O., ID 54445, VHA.

[42] Minna A., ID 54786, VHA.

[43] Naomi W., ID 55036, VHA.

[44] Oskar K., ID 53149, VHA.

[45] Paul L., ID 54767, VHA.

[46] Paul S., ID 38656, VHA.

[47] Peter A., ID 55428, VHA.

[48] Regina E., ID 53979, VHA.

[49] Rudolf S., ID 54608, VHA.

[50] Sara H.-H., ID 55443, VHA.

[51] Saul M., ID 6145, VHA.

[52] Siegi I., ID 55022, VHA.

[53] Renée D., ID 54875, VHA.

[54] Renee D., ID 53146, VHA.

[55] Rita K., ID 53023, VHA.

[56] Rose R., ID 55346, VHA.

\section{Literatura}

Bartoš, Vojtěch - Bauer, Michal - Chytilová, Julie - Matějka, Filip [2013]. Attention Discrimination: Theory and Field Experiments. CERGE-EI Working Paper Series 499. Dostupné z: <https://www.cerge-ei.cz /pdf/wp/Wp499.pdf >.

Bauman, Zygmunt [2010]. Modernita a holocaust (2. vyd.). Praha: Sociologické nakladatelství (SLON). Belpoliti, Marco [2003]. Hovory s Primo Levim (1963-1987). Praha - Litomyšl: Paseka.

Berger, Peter L. - Luckmann, Thomas [1999]. Sociální konstrukce reality: pojednání o sociologii vědèní. Brno: Centrum pro studium demokracie a kultury (CDK).

Bourdieu, Pierre. [1998]. Teorie jednání. Praha: Karolinum. 
Eglin, Peter - Hester, Stephen [2003]. The Montreal Massacre: A Story of Membership Categorization Analysis. Waterloo: Wilfrid Laurier University Press.

Finch, Janet [2008]. Naming Names: Kinship, Individuality and Personal Names. Sociology 42(4): 709-725.

Fitzgerald, Richard - Housley, William (ed.) [2015]. Advances in Membership Categorization Analysis. London: Sage.

Goffman, Erving [2003]. Stigma: Poznámky o způsobech zvládání narušené identity. Praha: Sociologické nakladatelství (SLON).

Hamar, Eleonóra [2010]. Vyprávěná židovství: O narativní konstrukci druhogeneračních židovských identit. Praha: Sociologické nakladatelství (SLON).

Havel, Václav - Kárný, Miroslav [1995]. Terezínská pamětní kniha: židovské oběti nacistických deportací $z$ Čech a Moravy 1941-1945. D. 1. Praha: Melantrich - Terezínská iniciativa.

Heim, Susanne [2008]. Die Verfolgung und Ermordung der europäischen Juden durch das nationalsozialistische Deutschland, 1933-1945. München: Oldenbourg.

Herbert, Ulrich - Orth, Karin - Dieckmann, Christoph [2002] Die nationalsozialistischen Konzentrationslager: Entwicklung und Struktur. Band 2. Frankfurt am Main: Fischer Taschenbuch.

Klemperer, Victor [2003]. Jazyk třetí ríšse - LTI: poznámky filologovy. Jinočany: H\&H.

Knappová, Miloslava [1989]. Rodné jméno v jazyce a společnosti. Praha: Academia.

Kogon, Eugen [1974]. Der SS-Staat: Das System der deutschen Konzentrationslager. München: Kindler Verlag.

Králová, Kateřina - Kubátová, Hana (ed.) [2016]. Návraty: Poválečná rekonstrukce židovských komunit v zemích středovýchodní, jihovýchodní a východní Evropy. Praha: Karolinum.

Levi, Primo [1995]. Je-li toto člověk. Praha: Sefer, nakladatelství Federace židovských obcí v České republice.

Mlynář, Jakub [2013]. Výroční setkání Centra vizuální historie Malach - 28. 1. 2013 [zpráva]. Historická sociologie (1): 119-120.

Mlynář, Jakub [2014]. Vztah paměti a identity v soudobé sociologii. In: Maslowski, Nicolas - Šubrt, Jiř́, a kol.: Kolektivní pamět: K teoretickým otázkám. Praha: Karolinum, s. 257-276.

Mlynár, Jakub [2015]. Unique Collection of Interviews with Armenian Genocide Witnesses and Survivors is Available at the Charles University in Prague [zpráva]. Historická sociologie (2): 126-128.

Mlynář, Jakub [2016]. Pluralita identit v autobiograckém vyprávění československých Židủ žijících v zahraničí. Historická sociologie (1): 33-51.

Mlynář, Jakub [2017]. Co máme na mysli, když říkáme „my“? Kolektivní identita, identifikace a kategorizace. In. Mlynár̆, Jakub - Paulíček, Miroslav - Šubrt, Jiří, a kol.: Člověk v teoretické perspektivě společenských věd. Praha: Karolinum, s. 60-76.

Mlynáŕ, Jakub - Kocian, Jiří - Bukovská, Karolína - Chudomelová, Lenka [2017]. Sociologie (a) orální historie: Archiv vizuální historie USC Shoah Foundation dostupný v Centru vizuální historie Malach při Univerzitě Karlově. Naše společnost 2: s. 52-55.

Mokrejš, Antonín. [2013]. Jméno - objev a zmizení věci. Praha: Academia.

Mücke, Pavel - Vaněk, Miroslav [2012]. Třetí strana trojúhelníku: Teorie a praxe orální historie. Praha: Fakulta humanitních studií Univerzity Karlovy.

Sofsky, Wolfgang [2006]. Řád teroru: koncentrační tábor. Praha: Argo.

Stivers, Tanya - Enfield, Nick J. - Levinson, Stephen C. [2007]. Person reference in interaction. In. Enfield, Nick J. - Stivers, Tanya (ed.): Person Reference in Interaction: Linguistic, cultural and social perspectives. Cambridge: Cambridge University Press, s. 1-20.

Ther, Philipp - Siljak, Ana [2001]. Redrawing Nations: Ethnic Cleansing in East-Central Europe, 1944-1948. Lanham: Rowman \& Littlefield.

\section{Internetové zdroje}

AfD-Anfrage im Saarland: Die meisten deutschen Messerangreifer heißen Michael [online]. Dostupné z: $<$ https://www.spiegel.de/politik/deutschland/afd-anfrage-im-saarland-die-meisten-messerangreifer -heissen-michael-a-1260240.html>. 
Fest der Freude am 8. Mai: Befreiung Österreichs vom Nationalsozialismus [online]. Dostupné z: <https:// www.mkoe.at/en/node/826>.

Hall of Names - www.yadvashem.org [online]. Dostupné z: <http://www.yadvashem.org/archive/hall -of-names>.

Liste vorgeschriebener Vornamen von 1938 [online]. Dostupné z: <http://www.beliebte-vornamen .de/3600-verzeichnis-juedischer-vornamen-1938.htm>.

Juden in Europa nach dem Zweiten Weltkrieg: 1945 bis 1989/90 bpb [online]. Dostupné z: <http://www .bpb.de/geschichte/nationalsozialismus/gerettete-geschichten/149156/juden-in-europa-nach-dem -zweiten-weltkrieg-1945-bis-1989-90>.

Portion of photo mural depicting Jewish Auschwitz survivors from Salonika, showing their tattooed arms on the third floor of the permanent exhibition of the U.S. Holocaust Memorial Museum - Collections Search United States Holocaust Memorial Museum [online]. Dostupné z: <https://collections.ushmm.org /search/catalog/pa1092951>.

Př́spèvek k dějinám Terezínských pamětních knih - Institut Terezínské iniciativy [online]. Dostupné z: $<$ http://www.terezinstudies.cz/publications/terezinske-pametni-knihy-20-let/k-historii-tpk-cz.html>.

Richtlinien über die Führung von Vornamen [online]. Dostupné z: <https://de.wikisource.org/wiki /Richtlinien_\%C3\%BCber_die_F\%C3\%BChrung_von_Vornamen>.

START: STOLPERSTEINE [online]. Dostupné z: <http://www.stolpersteine.eu/start>.

Switzerland during the war years (1914-1945) [online]. Dostupné $\mathrm{z}:<\mathrm{https} / / / \mathrm{www} . e d a . a d m i n . c h / d a m$ /PRS-Web/en/dokumente/die-schweiz-in-der-zeit-der-weltkriege_EN.pdf >.

Tattoos and Numbers: The System of Identifying Prisoners at Auschwitz [online]. Dostupné z: $<$ https://www .ushmm.org/wlc/en/article.php?ModuleId=10007056\#>.

Totenbuch KZ Sachsenhausen [online]. Dostupné z: <http://www.stiftung-bg.de/totenbuch $>$.

Úmluva o právech dítěte [online]. Dostupné z: <http://www.osn.cz/wp-content/uploads/2015/03/umluva -o-pravech-ditete.pdf>.

Veřejné čtení jmen obětí holocaustu - Jom ha-šoa [online]. Dostupné z: <http://www.terezinstudies.cz levents/jom-ha-soa>.

Wir müssen draußen bleiben: Warum Hanna zur Besichtigung eingeladen wird und Ismail nicht [online]. Dostupné z: <https://www.hanna-und-ismail.de/index.html >.

Židovská obec Brno - Stolpersteine [online]. Dostupné z: <https://www.zob.cz/kameny-zmizelych>.

Karolína Bukovská ( $\left.{ }^{*} 1994\right)$ absolvovala bakalářské dvouoborové studium Historie-Němčina pro mezikulturní komunikaci na Filozofické fakultě Univerzity Karlovy. V současnosti studuje jako stipendistka Německé akademické výměnné služby (DAAD) magisterský obor Public History na Freie Universität Berlin. Zaměřuje se na orální historii, pamětová studia a historickou kulturu. V roce 2018 se podílela na př́pravě jubilejních výstav v Karolinu a v Národním zemědělském muzeu. Je spoluautorkou článku Sociologie (a) orální historie: Archiv vizuální historie USC Shoah Foundation dostupný v Centru vizuální historie Malach při Univerzitě Karlově, který vyšel v časopise Naše společnost (2/2017).

Jakub Mlynár (“1984) vystudoval sociologii na Filozofické fakultě Univerzity Karlovy. Od roku 2010 působi jako koordinátor Centra vizuální historie Malach, které je českým př́stupovým místem $k$ Archivu vizuální historie USC Shoah Foundation, z něhož čerpá i tento článek. Od roku 2016 do roku 2018 absolvoval stáž na švýcarské Université de Fribourg. Disertační práci věnoval sociologické analýze orálněhistorických interview v kontextu společenskovědních teorií identity, narativity a paměti. Zajímá se též o dějiny a teorii sociologie, o etnometodologii a konverzační analýzu. Je autorem řady odborných statí a editorem či spoluautorem několika knih. 